\title{
Uso de un polímero hidrófilo en chile Anaheim (Capsicum annuum L.) bajo condiciones de invernadero
}

\author{
Use of a hydrophilic polymer in Anaheim pepper \\ (Capsicum annuum L.) under greenhouse conditions \\ Jesús López-Elías ${ }^{1 *}$, Marco Antonio Huez L., Edgar Omar Rueda P., \\ José Jiménez L., Fidencio Cruz B. y Oscar Garrido L.
}

\begin{abstract}
In order to improve the efficiency of water use in vegetable production, during autumn-winter 2011-2012 the use of a polyacrylamidebased hydrophilic polymer (PAM) was evaluated in Anaheim pepper cv. Cardon in full production using drip irrigation undergreenhouse conditions. The experimental design was a randomized complete block with five replicates. The experimental unit was $4 \mathrm{~m}$ long, $1.5 \mathrm{~m}$ wide $\left(6 \mathrm{~m}^{2}\right)$ with 20 total plants and five used for measurements. The parameters evaluated were: fruits per plant, fruit weight, commercial yield, size (length and diameter), volume of water applied, water use efficiency (WUE) and chlorophyll content. The incorporation of the hydrophilic polymer had no positive effect on production, fruit quality or WUE; however, there was an effect on the volume of applied water and chlorophyll content. With the polymer a yield of $1.5 \mathrm{~kg} \mathrm{~m}^{-2}$ with 24.9 fruits $\mathrm{m}^{-2}$, fruit weight $59.2 \mathrm{~g}, 16.2 \mathrm{~cm}$ length, $3.9 \mathrm{~cm}$ diametr, and WUE of $5.0 \mathrm{~kg} \mathrm{~m}^{-3}$ were obtained; whereas in the control without polymer the yield was $1.7 \mathrm{~kg} \mathrm{~m}^{-2}$, with 26.7 fruits $\mathrm{m}^{-2}$, fruit weight $62.1 \mathrm{~g}, 16.3 \mathrm{~cm}$ length, $4.0 \mathrm{~cm}$ diameter and WUE of $4.9 \mathrm{~kg} \mathrm{~m}^{-3}$. With the incorporation of the polymer a $1.5 \%$ increase in soil moisture content was obtained, which represented a $12 \%$ reduction in the volume of water applied and a SPAD reading of 58.4 versus 57.7 of the control, thus the use of a hydrophilic polymer may be an important practice for producers who need to irrigate less frequently and reduce watering time.
\end{abstract}

Key words: green pepper, hydrogel, water retention.

\section{RESUMEN}

Con el propósito de mejorar la eficiencia en el uso de agua en la producción de hortalizas, durante el ciclo otoño-invierno 2011 2012 se evaluó el uso de un polímero hidrófilo a base de poliacrilamida (PAM) en chile Anaheim cv. Cardón en plena producción usando riego por goteo bajo condiciones de invernadero. El diseño experimental fue bloques completos al azar con cinco repeticiones. Los parámetros evaluados fueron: frutos por metro cuadrado, peso del fruto, rendimiento, tamaño (longitud y diámetro), volumen de agua aplicada, eficiencia en el uso de agua (EUA) y contenido de clorofila. El polímero hidrófilo no presentó efecto positivo en la producción y calidad de fruto, al igual que en la EUA; sin embargo, hubo efecto en el volumen de agua aplicada y contenido de clorofila. Con el polímero se obtuvo un rendimiento de $1,5 \mathrm{~kg} \mathrm{~m}^{-2}, 24,9$ frutos $\mathrm{m}^{-2}$, peso por fruto de $59,2 \mathrm{~g}$, longitud de $16,2 \mathrm{~cm}$, diámetro de $3,9 \mathrm{~cm}$ y EUA de $5,0 \mathrm{~kg} \mathrm{~m}^{-3}$; mientras que el testigo obtuvo un rendimiento de $1,7 \mathrm{~kg} \mathrm{~m}^{-2}, 26,7$ frutos $\mathrm{m}^{-2}$, peso por fruto de 62,1 $\mathrm{g}$, longitud de $16,3 \mathrm{~cm}$, diámetro de 4,0 $\mathrm{cm}$ y EUA de $4,9 \mathrm{~kg} \mathrm{~m}^{-3}$. Con el polímero se tuvo un incremento del $1,5 \%$ en contenido de humedad en el suelo, que representó una reducción del $12 \%$ en el volumen de agua aplicada y una lectura SPAD de 58,4 contra 57,7 del testigo, por lo que el uso del polímero hidrófilo puede ser una práctica importante para productores que deseen aplicar riegos menos frecuentes, además de reducir el tiempo de riego.

Palabras clave: chile verde, hidrogel, retención hídrica.

\section{Introduction}

The state of Sonora is one of the main vegetableproducing zones in Mexico. It has one of the most important areas using irrigation technology in the country; however, the cost of water is high due to the energy used in its extraction. The volume of water is limited, and has been decreasing over time due to scarcity. The agricultural sector has taken steps to improve water use; however, studies

\footnotetext{
1 Universidad de Sonora, Departamento de Agricultura y Ganadería. Carretera Hermosillo a Bahía de Kino, Km. 21. Hermosillo, Sonora. México.

* Corresponding author: lopez_eliasj@guayacan.uson.mx
}

Fecha de Recepción: 20 Marzo, 2013.

Fecha de Aceptación: 28 Abril, 2013. 
of the recharging rate of the aquifer estimate it to be much lower than the extraction rate. Several groups andgovernment agencies have coincided in indicating that the reconversion of crops and irrigation technology are two key aspects for the efficient use of water. In summary, low water availability, increases in pumping costs and in the demand for water by diverse sectors of the society all urge the technological demand to make water use more efficient and assure agricultural profits, maintaining sustainability, preserving the aquifer and not deteriorating the environment.

Anaheim pepper (Capsicum annuиm L.) cv. Cardon is an economically important crop in Mexico, and is an alternative for protected agriculture. The production cost of this crop is approximately US\$ $7000 \mathrm{ha}^{-1}$ (SNIDRUS, 2012). In 2010 148,479 ha were planted, whose mean yield was $16.2 \mathrm{t} \mathrm{ha}^{-1}$; it was considered to be the main vegetable crop of the country. In Sonora 2,707 ha were planted in 2010 , with mean yield of $29.3 \mathrm{tha}^{-1}$ which ranked it among the six main vegetables; in Hermosillo's Coast 478 ha were planted this year, with a mean yield of $39.9 \mathrm{t} \mathrm{ha}^{-1}$ which ranked it among the five main vegetables (SIAP, 2012). In spite of the importance of the pepper crop, its yield is low in many regions of the country, probably due to inadequate agronomic management (fertilization, varieties and densities) or adverse environmental conditions (temperature, precipitation, soil not apt for the crop) and phytosanitary problems, thus there is a tendency to search for new production alternatives.

A more efficient management of water is possible with the use of hydrophilic polymers (hydrogels), which provide a clean and efficient alternative for agriculture. Hydrogels based on polyacrylamide started in the 1950s and posterior improvements increased their absorption capacity from 20 to 400 times their weight (Freitas et al., 2002). When water contacts these gels it is displaced towards the interior of the particles of the polymer; as the water diffuses the particle increases its size and the polymer chains move to allow more water molecules. At the same time, the presence of crosslinked points prevents the moving chains from separating and thus dissolving in the water (Barón et al., 2007).

More than 40 years of studies have shown the viability of hydrogel use to improve the absorption capacity of soil water, make better use of precipitation and reduce the loss irrigation water due to percolation and evaporation, reduce the lixiviation of nutrients and improve the aeration and drainage of soil. These factors permit longer times between irrigation, improve the development of root system and plant development, improve biological activity and increase production (Bres \& Weston, 1993; Ross et al., 2003; Rojas et al., 2004; Barón et al., 2007; Rivera et al., 2007); their effects are more evident in soils with high drainage (Barón et al., 2007; Idrobo et al., 2010), sandy texture (Ross et al., 2003) and in arid climates (Katime, 2003; Rojas et al., 2004; Barón et al., 2007; Alburquerque et al., 2009).

Rojas et al. (2004) observed that the hydrogel favored tomato germination and produced a positive effect on plant growth. Also in tomato, Rivera et al. (2007) reported an increase in dry weight of roots and fruits, associated with an increase in production. In coriander, hydrogel improved water use efficiency, yield of fresh and dry weight and the number of plants, depending upon irrigation and crop season (Alburquerque et al., 2009). Hydrogel produced good results in radish production, including an increase in retention of humidity and improved doses of fertilizers (Idrobo et al., 2010). The use of hydrogels in saline conditions in arid and semi-arid climates has great potential to reduce salt stress (Kant \& Turan, 2011). In terms of soil microbial activity, Sojka \& Entry (2000) and Sojka et al. (2006) reported that hydrogel reduced the active biomass of bacteria and fungus.

However, although there is evidence of the impact of the use of hydrogels in agriculture with gravity irrigation, there has been little research on its use with irrigation technology. Thus this study evaluated the use of a polyacrylamide-based hydrophilic polymer in Anaheim pepper grown in a greenhouse using irrigation technology to evaluate its effects in the agronomic management of the crop.

\section{Materials and Methods}

This study was performed in a greenhouse of the Campo Agrícola Experimental of the Departamento de Agricultura y Ganadería of the Universidad de Sonora at $29^{\circ} 00^{\prime} 48^{\prime \prime} \mathrm{N}, 111^{\circ} 08^{\prime} 07^{\prime}$ ' W and $151 \mathrm{~m}$ elevation during the 2011-2012 autumn-winter growing season. The greenhouse has a surface of $225 \mathrm{~m}^{2}$ and was covered with 8 mil thickness polyethylene, humid walls, two fans and no heating system. The soil has sandy loam texture; irrigation water had electrical conductivity of $0.57 \mathrm{dSm}^{-1}$ and $\mathrm{pH} 7.2$. 
The crop evaluated was Anaheim (Capsicum annиит L.) cv. Cardon pepper in full production, which was transplanted on 24 August 2011. Plantation density was 3.3 plants $\mathrm{m}^{-2}$, in double rows separated by $40 \mathrm{~cm}$, with $40 \mathrm{~cm}$ between plants and $1.5 \mathrm{~m}$ between rows. Once the crop was established it was managed as usual by the producer, including preventive applications and chemical control of diseases and insects.

Below the cross of the main stem all branches were eliminated and plants were later entrained using horizontal supports of polypropylene ramie fiber attached to wooden stakes placed every 2.5 $\mathrm{m}$ on both sides of the rows.

Irrigation was by means of drips which provided $2.0 \mathrm{~L} \mathrm{~h}^{-1}$. Soil humidity was measured daily in the morning during the entire crop cycle using tensiometers placed at $20 \mathrm{~cm}$ depth; when the reading reached $20 \mathrm{kPa}$ plants were irrigated until a value of 10-12 $\mathrm{kPa}$ was recorded.

The total fertilization was $290 \mathrm{~N}-155 \mathrm{P}-380 \mathrm{~K}-$ $110 \mathrm{Ca}-85 \mathrm{Mg} \mathrm{kgha}^{-1}$, distributed during the crop cycle, adjusted according to the initial soil analysis and leaf analyses performed every two weeks.

The experimental design was randomized complete blocks with two treatments and five replications. The treatments evaluated were; a commercial dose of a polyacrylamide-based hydrophilic polymer (PAM), Lluvia sólida ${ }^{\circledR}(25 \mathrm{~kg}$ $\mathrm{ha}^{-1}$ ) and the control. The previously hydrated polymer was placed laterally at $10 \mathrm{~cm}$ from the plant at a depth of $15 \mathrm{~cm}$. The experimental area was $113 \mathrm{~m}^{2}$, within which 10 experimental units of $6 \mathrm{~m}^{2}$ were established ( $4.0 \mathrm{~m}$ length, $1.5 \mathrm{~m}$ width) with 20 total plants and five used for measurements.

We evaluated commercial production (fruits $\mathrm{m}^{-2}$, fruit weight and yield), fruit quality (length and diameter), volume of water applied, water use efficiency (WUE) and chlorophyll content. Fruits were weighted using an Avery Berkel 6405 digital scale with $5 \mathrm{~g}$ precision. Fruit length was measured with a metallic tape with $1 \mathrm{~mm}$ precision. Fruit diameter was measured with a Mitutoyo CD-6" CS digital Vernier with $0.01 \mathrm{~mm}$ precision. Chlorophyll content was estimated using a SPAD 502 (Minolta $\left.{ }^{\circledR}\right)$, which measures leaf absorbance in red $(600-700 \mathrm{~nm})$ and near infrared $(>700 \mathrm{~nm}$ ) wavelengths. Harvested fruits were sorted according to size $(15-25 \mathrm{~cm}$ length), uniform green color and straight, smooth surface. Five harvests were made, the first at the beginning of March, 2012 and the last during May.
Data were analyzed using SAS 6.12 (SAS Institute Inc., 1996). After the ANOVA we used Duncan's multiple range test with a significance level of 0.05 .

\section{Results and Discussion}

The production parameters (Table 1) numbers of fruit per square meter, fruit weight and yield, and the quality parameters (Table 2) fruit length and diameter were all slightlygreater in the control; however, none of the differences were statistically significant. This indicates that these variables were not importantly affected by the addition of the hydrophilic polymer. Although it has been shown that hydrophilic polymers are a beneficial practice to improve yield and fruit quality in a number of crops (Nissen and San Martín, 2004; Ezzat et al., 2011), in this study we did not find a positive effect of the polymer on fruit yield or quality in Anaheim cv. Cardón pepper. This coincides with the results of studies in wheat (Nissen and García, 1997) and in potatoes (Ezzat et al., 2011); the polymer may be useful in conditions of moderate to extreme

Table 1. Fruits $\mathrm{m}^{-2}$, fruit weight $(\mathrm{g})$ and yield $\left(\mathrm{kg} \mathrm{m}^{-2}\right)$ in Anaheim pepper (Capsicum annuиm L.) cv. Cardon under greenhouse conditions.

\begin{tabular}{lccc}
\hline Treatment & $\begin{array}{c}\text { Fruit } \\
\mathrm{m}^{-2}\end{array}$ & $\begin{array}{c}\text { Fruit weight } \\
(\mathrm{g})\end{array}$ & $\begin{array}{c}\text { Yield } \\
\left(\mathrm{kg} \mathrm{m}^{-2}\right)\end{array}$ \\
\hline Control & 26.7 & 62.1 & 1.7 \\
Polymer & 24.9 & 59.2 & 1.5 \\
Significance & $\mathrm{ns}$ & $\mathrm{ns}$ & $\mathrm{ns}$ \\
c.v. $(\%)$ & 21.2 & 2.8 & 27.8 \\
\hline
\end{tabular}

$*$,**, ns, are $p \leq 0.05, p \leq 0.01$ and not significant.

Table 2. Fruit length $(\mathrm{cm})$ and diameter $(\mathrm{cm})$ in Anaheim pepper (Capsicum annuum L.) cv. Cardon under greenhouse conditions.

\begin{tabular}{lcc}
\hline Treatment & $\begin{array}{c}\text { Length } \\
(\mathrm{cm})\end{array}$ & $\begin{array}{c}\text { Diameter } \\
(\mathrm{cm})\end{array}$ \\
Control & 16.3 & 4.0 \\
Polymer & 16.2 & 3.9 \\
Significance & $\mathrm{ns}$ & $\mathrm{ns}$ \\
c.v. $(\%)$ & 1.9 & 1.8 \\
\hline
\end{tabular}

$*, * *, \mathrm{~ns}$, are $p \leq 0.05, p \leq 0.01$ and not significant. 
water stress, in arid and semi-arid zones with less than $350 \mathrm{~mm}$ annual precipitation and with erratic distribution (Savé et al., 1995).

With the addition of the polymer, after irrigation there was an increase of $1.5 \%$ in the soil humidity (data not shown), coinciding with the studies of Bres \& Weston (1993), Akhter et al. (2004), Bhardwaj et al. (2007), Bhat et al. (2009) y Dorraji et al. (2010), reducing the volume of water applied by $12 \%$ (Table 3) and increasing the time between irrigations by two days. These results are similar to those of Akhter et al. (2004), who evaluated the effect of the polymer in the water retention capacity in different soils, Campos et al. (2005) in melons and Agaba et al. (2011) in grasses; the savings in water and electrical energy will be considerable considering the entire crop cycle.

Although the water use efficiency (Table 2), expressed in $\mathrm{kg} \mathrm{m}^{-3}$ of water applied to the crop, was slightly greater with the addition of the hydrophilic polymer $\left(5.0 \mathrm{~kg} \mathrm{~m}^{-3}\right)$, the differences among treatments were not significant.
There were significant differences in chlorophyll content (Table 3) among treatments; the addition of the hydrophilic polymer increased the SPAD reading by $1.2 \%$. Readings decreased after irrigation; there was a greater decrease over time without the polymer (data not shown), which may be due to the retention of fertilizer by the polymer and its posterior slow liberation (Bres \& Weston, 1993).

\section{Conclusions}

Addition of the polyacrylamide-based hydrophilic polymer did not produce effects on the production, fruit quality or water use efficiency in Anaheim peppers grown in a greenhouse with drip irrigation. The use of the polymer increased soil water content, favoring a reduction in applied water and lower irrigation frequency without affecting the crop, and also increasing the chlorophyll content of the plant. The use of hydrophilic polymers may be an important practice for producers who wish to apply less frequent irrigation and reduce irrigation time.

Table 3. Volume of water applied $\left(\mathrm{m}^{-3}\right)$, water use efficiency $\left(\mathrm{kg} \mathrm{m}^{-3}\right)$ and chlorophyll content in Anaheim pepper (Capsicum annum L.) cv. Cardon under greenhouse conditions.

\begin{tabular}{lccc}
\hline Treatment & $\begin{array}{c}\text { Volume of } \\
\text { water applied }\left(\mathrm{m}^{-3}\right)\end{array}$ & $\begin{array}{c}\text { WUE } \\
\left(\mathrm{kg} \mathrm{m}^{-3}\right)\end{array}$ & $\begin{array}{c}\text { Chlorophyll content } \\
\text { (SPAD reading) }\end{array}$ \\
\hline Control & $3370 \mathrm{a}$ & 4.9 & $57.7 \mathrm{a}$ \\
Polymer & $2970 \mathrm{~b}$ & 5.0 & $58.4 \mathrm{~b}$ \\
Significance & $* *$ & $\mathrm{~ns}$ & $*$ \\
c.v. $(\%)$ & 1.3 & 24.2 & 3.8 \\
\hline
\end{tabular}

$*, * *, \mathrm{~ns}$, are $p \leq 0.05, p \leq 0.01$ and not significant.

\section{Literature Cited}

Agaba, H.; Lawrence, J.B.O.; Obua, J.; Kabasa, J.D.; Worbes, M. 2011. Hydrogel amendment to Sandy soil reduces irrigation frequency and improves the biomass of Agrostis stolonifera. Agricultural Sciences 2 (4): 54-550.

Akhter, J.; Mahmood, K.; Malik, K.A.; Mardan, A.; Ahmad, M.; Iqbal, M.M.

2004. Effects of hydrogel amendment on water storage of sandy loam and loam soils and seedlinggrowth of barley, wheat and chickpea. Plant Soil Environ. 50 (10): 463-469. Alburquerque, J.A.C.; De Lima, V.L.A.; Menezes, D.; Azevedo, C.A.V.; Dantas, J.; Da Silva, J.G.

2009. Características vegetativas do coentro submetido a doses do polímero hidroabsorvente e lâminas de irrigação. Revista Brasileira de Engenharia Agrícola e Ambiental 13 (6): 671-679.
Barón, A.; Barrera, I.X.; Boada, L.F.; Rodríguez, G. 2007. Evaluación de hidrogeles para aplicaciones agroforestales. Revista Ingeniería e Investigación 27 (3): $35-44$.

Bhardwaj, A.K.; Shainberg, I.; Goldstein, D.; Warrington, D.N.; Levy, G.J.

2007. Water retention and hydraulic conductivity of crosslinked polyacrylamides in sandy soils. Soil Sci. Soc. Am. J. 71 (2): 406-412.

Bhat, N.R.; Suleiman, M.K.; Al-Menaie, H.; Al-Ali, E.H.; Al-Mulla, L.; Christopher, A.; Lekha, V.S.; Ali, S.I.; George, P. 2009. Polyacrylamide polymer and salinity effects on water requirement of Conocarpus lancifolius and selected properties of sandy loam soil. European Journal of Scientific Research 25 (4): 549-558. 
Bres, W.; Weston, L.A.

1993. Influence ofgel additives on nitrate, ammonium and water retention and tomatogrowth in a soilless medium. Horticulture Science 28 (10): 1005-1007.

Campos, A.C.; Lucena, S.R.; Schmitz, A.A.

2005. Produção de meloeiro utilizando um polímero hidrofílico em diferentes freqüências de irrigação em casa-de-vegetação. Irriga, Botucatu 10 (1): 82-87.

Dorraji, S.S.; Golchin, A.; Ahmadi, S.

2010. The effects of hydrophilic polymer and soil salinity on corngrowth in Sandy and loamy soils. Clean - Soil, Air, Water 38 (7): 584-591.

Ezzat, A.E.; El-Awady, A.A.; Ahmed, H.M.

2011. Improving nitrogen utilization efficiency by potato (Solanum tuberosum L.). Nature and Science 9 (7): 34-42.

Freitas, T.L.; Bertonha, A.; Andrade, A.C.

2002. Uso de hidrogel na agricultura. Revista do Programa de Ciências Agro-Ambientais, Alta Floresta 1 (1): 23-31.

Idrobo, H.; Rodríguez, A.M.; Díaz, J.E.

2010. Comportamiento del hidrogel en suelos arenosos. Ingeniería de Recursos Naturales y del Ambiente 9: 33-37.

Kant, A.C.; Turan, M.

2011. Hydrogel substrate alleviates salt stress with increase antioxidant enzymes activity of bean (Phaseolus vulgaris L.) under salinity stress. African Journal of Agricultural Research 6 (3): 715-724.

Katime, I.A.

2003. Hidrogeles inteligentes. Revista Iberoamericana de Polímeros 4 (2): 11-42.

Nissen, J.; García, R.

1997. Efecto del uso de una poliacrilamida en la lixiviación de nitrógeno y de potasio sobre trigo (Titricum sp.), en un suelo volcánico. Agro sur 25 (2): 196-202.

Nissen, J.; San Martín, K.

2004. Uso de poliacrilamidas y el riego en el manejo hídrico de lechugas (Lactuca sativa L.). Agro sur 32 (2): 1-12.

Rivera, C.A.; Baeza, C.A.; Chavarriaga, W.

2007. Efecto de un retenedor de agua y dosis crecientes de fertilizantes foliares sobre la producción de tomate chonto y larga vida bajo cubierta plástica agroclear. Agron. 15 (1): 103-119.

Rojas, B.; Aguilera, R.; Prin, J.L.; Cequea, H.; Cumana, J.; Rosales, E.; Ramírez, M.

2004. Estudio de lagerminación de semillas de tomate en suelos áridos extraídos de la península de Araya (Venezuela) al utilizar polímeros de tipo hidrogeles. Revista Iberoamericana de Polímeros 5 (1): 17-27.

Ross, C.W.; Sojka, R.E.; Foerster, J.A.

2003. Scanning electron micrographs of polyacrylamidetreated soil in irrigation furrows. J. Soil Water Conservation 58 (5): 327-331.

Savé, R.; Pery, M.; Marfá, O.; Serrano, L.

1995. The effect of a hydrophilic polymer on plant water status and survival of transplanted pine seedlings. Hort Technology 5 (2): 141-143.

SAS Institute Inc.

1996. The SAS System for Windows Release 6.12. Cary, N.C. USA.

SIAP.

2012. Análisis estadístico de producción agrícola. Secretaría de Agricultura, Ganadería, Desarrollo Rural, Pesca y Alimentación (SAGARPA). Servicio de Información Agroalimentaria y Pesquera (SIAP). México. http://www. siap.gob.mx. Consultado: 20/06/2012.

SNIDRUS.

2012. Costo de producción chile tecnificado ciclo OI 20112012. Secretaría de Agricultura, Ganadería, Desarrollo Rural, Pesca y Alimentación (SAGARPA). Sistema Nacional de Información para el Desarrollo Rural Sustentable (SNIDRUS). http://www.oeidrus-portal.gob.mx/oeidrus_son. Consultado: 20/06/2012.

Sojka, R.E.; Entry, J.A.

2000. Influence of polyacrylamide application to soil on movement of microorganisms in runoff water. Environmental Pollution 108 (3): 405-412.

Sojka, R.E.; Entry, J.A.; Fuhrmann, J.J.

2006. The influence of high application rates of polyacrylamide on microbial metabolic potential in an agricultural soil. Applied Soil Ecology 32 (2): 243-252. 
